\title{
Article
}

\section{Assessment of Copper and Heavy Metals in Family-Run Vineyard Soils and Wines of Campania Region, South Italy}

\author{
Valentina Roviello ${ }^{1, *(1)}$, Ugo Caruso ${ }^{2}\left(\right.$, Giovanni Dal Poggetto ${ }^{3}$ and Daniele Naviglio ${ }^{2} \mathbb{C}$ \\ 1 Department of Chemical, Materials and Industrial Production Engineering (DICMaPI), University of Naples \\ Federico II, Piazzale V. Tecchio 80, 80125 Naples, Italy \\ 2 Department of Chemical Sciences, University of Naples Federico II, Via Cintia 21, 80126 Naples, Italy; \\ ugo.caruso@unina.it (U.C.); daniele.naviglio@unina.it (D.N.) \\ 3 Ecoricerche s.r.l, Via Principi Normanni 36, 80143 Capua, Italy; giogiodp@hotmail.it \\ * Correspondence: valentina.roviello@unina.it; Tel.: +39-346-644-4862
}

Citation: Roviello, V.; Caruso, U.; Dal Poggetto, G.; Naviglio, D. Assessment of Copper and Heavy Metals in Family-Run Vineyard Soils and Wines of Campania Region, South Italy. Int. J. Environ. Res. Public Health 2021, 18, 8465. https://doi.org/10.3390/ ijerph18168465

Academic Editor: Yuping Qiu

Received: 19 July 2021

Accepted: 9 August 2021

Published: 11 August 2021

Publisher's Note: MDPI stays neutral with regard to jurisdictional claims in published maps and institutional affiliations.

Copyright: (c) 2021 by the authors. Licensee MDPI, Basel, Switzerland. This article is an open access article distributed under the terms and conditions of the Creative Commons Attribution (CC BY) license (https:// creativecommons.org/licenses/by/ $4.0 /)$.

\begin{abstract}
Copper-based phytosanitary treatments are widely employed in viticulture for combating the fungal diseases of European grape (Vitis vinifera L.). Herein we evaluated copper accumulation in the soil of a 50-year-old still productive vineyard in South Italy in comparison with samples taken from a 'control' area in which grapevines had never been cultivated, as well from an abandoned vineyard, now planted with cereals and forage crops, both close to the main area under investigation. Even though the heavy metal contents detected were not of concern for soils nor for wine, $\mathrm{Cu}$ accumulates in the soil in amounts significantly higher than the (grapevine free) control and remains at detectable concentrations also in abandoned vineyards where spraying activities had ceased about 20 years before this study. Despite the long $\mathrm{Cu}$ residence times in soil, the wine produced with grapes of the same vineyard showed $\mathrm{Cu}$ levels low enough to be safely used for human consumption, probably due to mechanisms of metal precipitation occurring during wine maturation, which are typically accompanied by sedimentation processes in artisanal production. However, this should not diminish the urgency of decreasing the copper usage as antifungal remedy in viticulture to prevent copper contamination of the agricultural soils.
\end{abstract}

Keywords: copper accumulation; copper toxicity; wine analysis; heavy metals

\section{Introduction}

Vine growing and wine-making have been prominent in Europe, and particularly in Italy, since antiquity [1]. Viticulture requires numerous phytosanitary treatments for vine disease management during the pre-flowering stage through 2-4 weeks after the flowering period $[2,3]$. Among the phytosanitary interventions, those directed to control downy mildew (caused by Plasmopara viticola) are based on copper-containing products, with rameic sulphate + calcium hydroxide/copper oxychloride being one of the most common treatments [4-6]. In turn, these products can be used in combination with other phytosanitary drugs. Typically, $\mathrm{Cu}$ content in the most common copper-based products for agriculture ranges from 35 to $50 \%(w / w)$ with amounts as high as $3-5 \mathrm{~kg} \mathrm{Cu}$ per hectare of vineyard [7]. The total number of phytosanitary treatments needed yearly is in strong correlation with factors such as weather conditions, latitude, and grapevine breed, and rarely is lower than four with the dispersion of about $8 \mathrm{~kg} \mathrm{Cu}$ per hectare/year [8].

The fate of copper from fungicides includes about $90 \%$ deposited in the soil through both direct dispersion and wash-out from leaf surface or branches in decomposition. When present in neutral or slightly basic soil, $\mathrm{Cu}$ leads to different compounds all converging with time toward the highly insoluble $\mathrm{CuO}$ (having a solubility product $\mathrm{Ksp}=10^{-19.51}$, $298 \mathrm{~K}$ [9]). This leads to copper accumulation in the soil $[10,11]$ and when $\mathrm{pH}$ locally decreases, for example in the proximity of the plant roots as a consequence of organic 
matter decomposition, $\mathrm{Cu}$ dissolves and can be more easily absorbed by plants [12]. Familyrun vineyards can remain productive also after one century or longer [13]. Hence, $\mathrm{Cu}$ concentration in soils of traditional vineyards, and to a lower extent also of younger industrial vineyards, can be particularly high, leading to environmental contamination.

In fact, amounts as high as $300 \mathrm{~kg}$ of $\mathrm{Cu}$ per hectare are typically released to a vineyard soil after one century [14]. However, this estimation is approximate because it considers as additive the amounts of copper used yearly, while one should consider that part of copper is eliminated in waters for example through percolation in loose soils or washout mainly from sloping sites [15].

Several analytical methods were applied to vineyard soil characterization [16] with particular attention paid to $\mathrm{Cu}$ contents [17,18], whose detection is particularly important also in wine analysis $[19,20]$. However, to the best of our knowledge there are no comparative heavy metal assessments taking into consideration contemporarily 1 -vineyards subjected to Cu-based phytosanitary treatments; 2-adjacent control plots; and 3-adjacent former vineyards where grapevine cultivation was discontinued tens of years before the study.

Hence, in the present study we report and compare data on the composition of a homogeneous soil from three adjacent sites within a radius of $100 \mathrm{~m}$. These include a 50-year-old and still productive vineyard (indicated as V50, Figure 1); an adjacent field planted with cereals and forage since centuries (Tr); and a former vineyard (T20) adjacent to site 2, in production in the 1950-2000 period, now planted with rotating cereals and forage crops. V. Roviello, whose family inherited in part these plots, is aware of the reported information on the above-mentioned sites. In addition to the already mentioned soil analyses, we have extended our study also to grapevine branches and wines obtained from the site 1 (Figure 1).

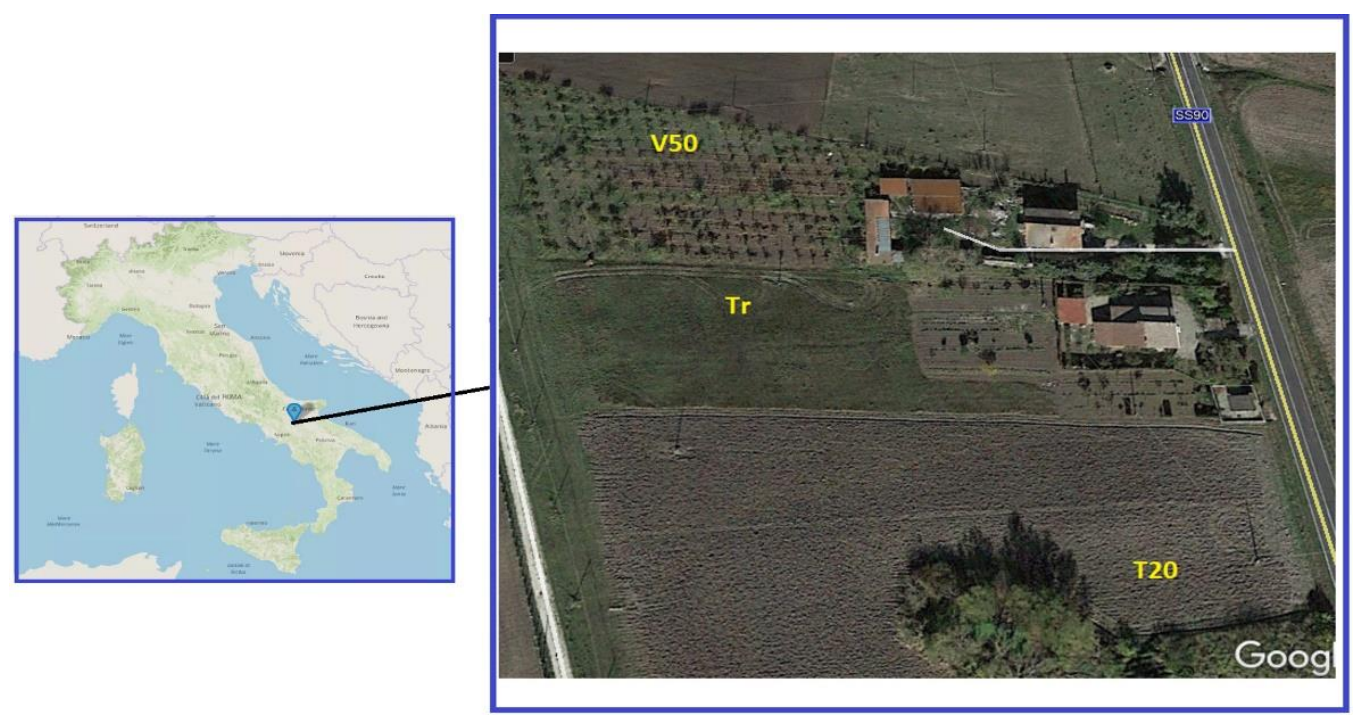

Figure 1. Map localization and satellite image with the area of study described in the present work. Images adapted from www.tuttocitta.it (left) (accessed on 10 August 2021) and Google Earth (right, Google, Maxar Technologies).

\section{Materials and Methods}

\subsection{Soil Sampling and Site Description}

Samples used for the analyses were obtained mixing equal amounts (not less than $10 \mathrm{Kg}$ each) of soil samples taken from $\sim 20 \mathrm{~cm}$ deep from four equivalent points in the same plot at a mutual distance of about $50 \mathrm{~m}$. In V50, which contains about 300 50-year-old vines, sampling was performed in the proximity of the grapevine trunk (sample $1 \mathrm{~A}$ ) and in the crossing point (1B) of the two diagonals of the square formed by four adjacent grapevines at a mutual distance of about $5 \mathrm{~m}$. Similarly, for Tr and T20 we took the samples 2 and 3, 
respectively, obtained mixing four equivalent amounts of soil taken from four points that were equidistant from the vertices of the ideal rectangles enclosing the plots of land under exam. The physicochemical characterization of the soil in the area under investigation (territory of Ariano Irpino, Campania Region, Italy) was published recently [21] and shows that clay and silt are predominant accounting for more than $44 \%$ and $25 \%$, respectively. On the other hand, $\mathrm{pH}$ is slightly basic (7.3), and N-total is about $0.9 \mathrm{~g} / \mathrm{kg}$ [21]. Details including records from the local land registry (Cadaster) of the plots studied by us are reported in Table 1.

Table 1. Details and description of the plots studied within a flat area situated in the territory of the municipality of Ariano Irpino (Campania region, Italy).

\begin{tabular}{cccc}
\hline ID Site & V50 & Tr & T20 \\
\hline Latitudo $\left({ }^{\circ} \mathbf{N}\right)$ & $41^{\circ} 11^{\prime} 35.92^{\prime \prime}$ & $41^{\circ} 11^{\prime} 34.68^{\prime \prime}$ & $41^{\circ} 11^{\prime} 31.65^{\prime \prime}$ \\
\hline Longitudo $\left({ }^{\circ} \mathbf{E}\right)$ & $15^{\circ} 08^{\prime} 07.66^{\prime \prime}$ & $15^{\circ} 08^{\prime} 07.51^{\prime \prime}$ & $15^{\circ} 08^{\prime} 10.08^{\prime \prime}$ \\
\hline $\begin{array}{c}\text { Land Surface } \\
\text { Areas (sq.m) }\end{array}$ & 4.4 & 3.33 & 800 \\
\hline $\begin{array}{c}\text { Details } \\
\text { from Cadaster }\end{array}$ & $\begin{array}{c}\text { Folio number 13, } \\
\text { Parcel number 248 }\end{array}$ & $\begin{array}{c}\text { Folio number 13, } \\
\text { Parcel number 247 }\end{array}$ & $\begin{array}{c}\text { Folio number 13, } \\
\text { Parcel number 246 }\end{array}$ \\
\hline
\end{tabular}

\subsection{Grapevine Branches and Wine Samples}

Grapevine branches (sample 4), the results of the annual pruning, were cut in January 2021 , i.e., the same period in which we took the soil samples for this study. We obtained the $\mathrm{A} 2000 \mathrm{~V}$ (sample 7) sample from the 2000 vintage red wine (skin-fermented), and the following red wine samples, each from the 2020 vintage, with a volume of $2 \times 1 \mathrm{~L}$ : A20V (sample 5): skin-fermented; A20SV (sample 6): fermented without any skin contact; C20: must from not sprayed grape fermented without any skin contact; A20V, A20SV and C20 were analyzed 6 months after the fermentation, following two settling steps on the naturally-clarified wine.

\subsection{Chemical Analysis of Soil and Wine Samples}

The chemical analysis of soil (1A, 1B, 2, 3, and 4) and wine samples $(5,6$, and 7$)$ was performed by inductively coupled plasma-optical emission spectrometry. Soil samples were dissolved in $\mathrm{HNO}_{3}$ suprapure solution (Nitric acid $65 \%(w / v)$, Suprapure for trace analysis, Merck, VWR International Srl, Milan, Italy).

The metal content of all samples was investigated by microwave-assisted wet digestion (Microwave Mineralizer Speedwave4, Buchi, Flawil, Switzerland) according to EPA 3051A:2007 [22]. The determination was made using an Inductively coupled plasma-optical emission spectrometer (ICP-OES 5110, Agilent Tech, Santa Clara, CA, USA). The analyses of all samples were conducted based on calibration lines built according to EPA 6010 [23].

\section{Results and Discussion}

Grapevine cultivation requires, for disease control, frequent treatments with copper sulphate acting as a fungicide, especially in mixture with calcium oxide in the so-called "Bordeaux Mixture" [24,25], which is used for treatment of the vineyard object of the present analytical investigation. The soil under analysis was found to be clay-rich. The surface layer with a variable thickness of about $0.5 \mathrm{~m}$ is rich in humus and looks black in color: it is quite permeable to meteoric waters. The deepest layer, made up of yellow clay, absorbs water, and to a limited extent becomes impermeable.

Moreover, the site under study is flat and is not subject to any significant precipitation washout in the presence of abundant rainfall. Thus, both layers are effective absorbing and ion-trapping model systems. 


\subsection{Soil Analysis}

The chemical analysis (Table 2) of all soil samples taken as depicted in Figure 2 was performed by ICP-OES. Table 2 shows the results as ppm values of the various metals analyzed. The limit of quantification (LOQ) is $5 \mathrm{ppb}$, which means that below $5 \mathrm{ppb}$ the readings are not reliable from a quantitative point of view, while they only give us information about the detectability. It can be observed that there is an abundant presence of $\mathrm{Fe}, \mathrm{Al}, \mathrm{Mn}$, and $\mathrm{Cu}$. On the other hand, $\mathrm{Ca}, \mathrm{Hg}, \mathrm{K}, \mathrm{Mg}$, Se, and $\mathrm{Cr}(\mathrm{VI})$ are present in quantities lower than the LOQ. The analysis results for the four samples with respect to all parameters but copper amounts are very similar and in line with the expected results [26]: We found high levels of aluminum due to the presence of aluminosilicates in clay, considerable amounts of iron, and also significant levels of manganese. Other ubiquitous elements were found to be present in moderate quantity $(\mathrm{Co}$, total $\mathrm{Cr}, \mathrm{N}, \mathrm{Pb}, \mathrm{V}$, and $\mathrm{Zn})$, whilst the most harmful were detected at low levels or below the detection threshold ( $\mathrm{As}, \mathrm{Be}, \mathrm{Cd}, \mathrm{Hg}$, $\mathrm{Tl}$, and $\mathrm{Cr}(\mathrm{VI})$ ). As far as copper content is concerned, a significantly variable quantity for this metal was detected in our samples probably associated to anthropic activities.
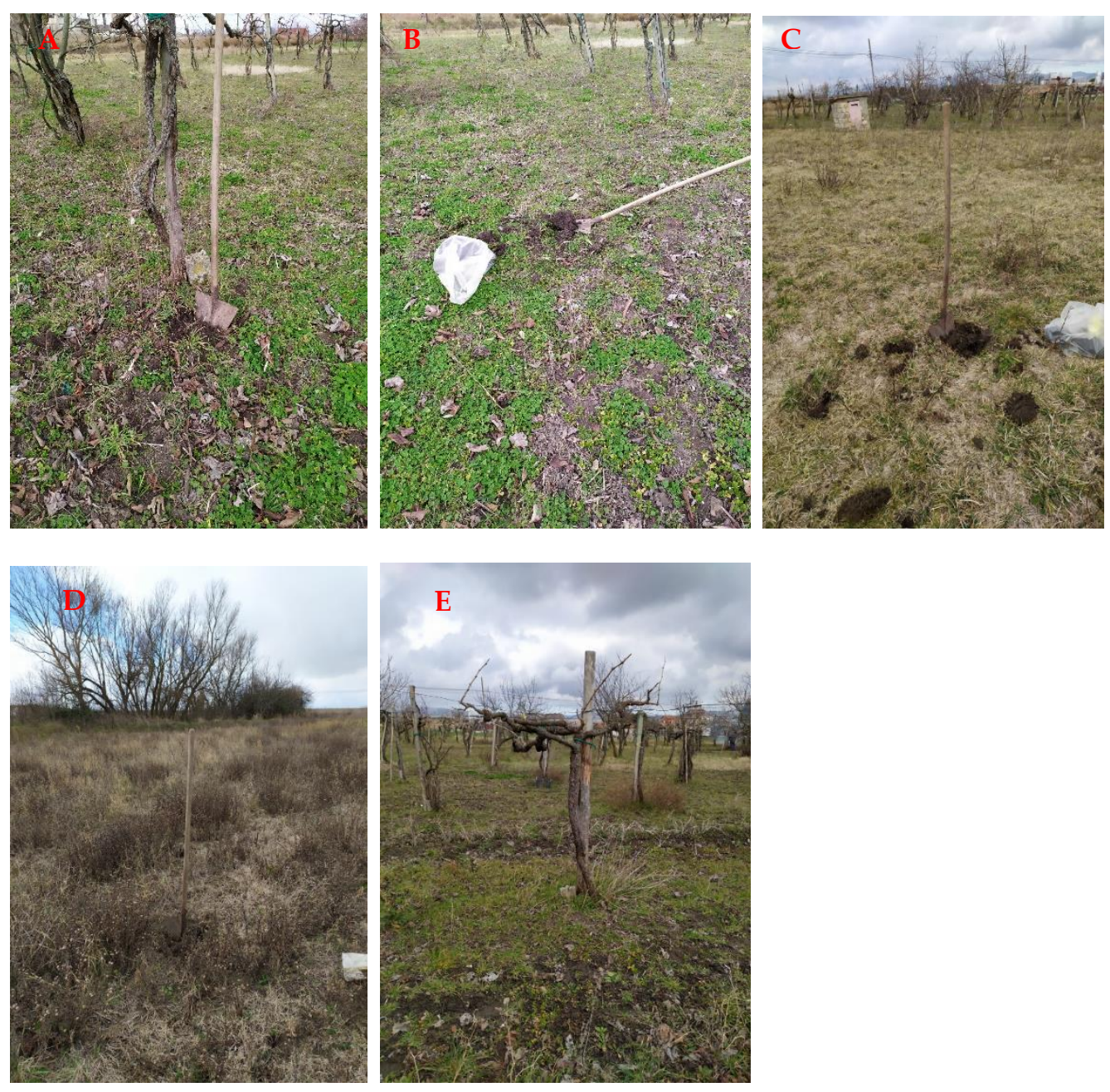

Figure 2. Sampling at the foot of the grapevines in V50 (A); in the middle of the grapevines in V50 (B); in a grapevine-free control area (Tr), (C); in ST20 (D). A 50-year-old grapevine specimen (E). 
Table 2. Analysis of soil samples: listed values (as ppm) are means of triplicate determination \pm SD.

\begin{tabular}{cccccc}
\hline Metal & Sample 1A & Sample 1B & Sample 2 & Sample 3 & Sample 4 \\
\hline $\mathrm{Al}$ & $32,879 \pm 350$ & $35,967 \pm 375$ & $41,273 \pm 435$ & $34,141 \pm 330$ & $36.03 \pm 0.50$ \\
\hline $\mathrm{As}$ & $13.41 \pm 0.18$ & $11.94 \pm 0.15$ & $11.26 \pm 0.16$ & $14.60 \pm 0.20$ & $0.29 \pm 0.04$ \\
\hline $\mathrm{Be}$ & $3.36 \pm 0.08$ & $3.42 \pm 0.10$ & $3.52 \pm 0.10$ & $2.58 \pm 0.05$ & $<5 \mathrm{ppb}$ \\
\hline $\mathrm{Cd}$ & $0.57 \pm 0.03$ & $0.63 \pm 0.04$ & $0.54 \pm 0.03$ & $0.50 \pm 0.03$ & $<5 \mathrm{ppb}$ \\
\hline $\mathrm{Co}$ & $24.14 \pm 0.30$ & $18.85 \pm 0.25$ & $18.22 \pm 0.28$ & $12.65 \pm 0.18$ & $0.10 \pm 0.03$ \\
\hline $\mathrm{Cr}$ tot & $24.50 \pm 0.22$ & $20.99 \pm 0.17$ & $22.22 \pm 0.20$ & $19.85 \pm 0.18$ & $0.44 \pm 0.02$ \\
\hline $\mathrm{Cu}$ & $180.47 \pm 2.22$ & $129.27 \pm 1.15$ & $35.41 \pm 0.88$ & $121.63 \pm 1.75$ & $16.59 \pm 0.45$ \\
\hline $\mathrm{Fe}$ & $22,925 \pm 250$ & $24,321 \pm 330$ & $25,725 \pm 458$ & $22,250 \pm 290$ & $45.40 \pm 0.66$ \\
\hline $\mathrm{Hg}$ & $<5 \mathrm{ppb}$ & $<5 \mathrm{ppb}$ & $<5 \mathrm{ppb}$ & $<5 \mathrm{ppb}$ & $<5 \mathrm{ppb}$ \\
\hline $\mathrm{Mn}$ & $1901.7 \pm 20.3$ & $1400.3 \pm 17.8$ & $1295.5 \pm 15.9$ & $910.53 \pm 12.6$ & $32.27 \pm 0.49$ \\
\hline $\mathrm{Ni}$ & $26.78 \pm 0.34$ & $19.76 \pm 0.29$ & $20.53 \pm 0.31$ & $18.94 \pm 0.33$ & $0.37 \pm 0.01$ \\
\hline $\mathrm{Pb}$ & $89.89 \pm 0.95$ & $81.50 \pm 0.88$ & $92.82 \pm 1.06$ & $73.94 \pm 0.99$ & $7.90 \pm 0.30$ \\
\hline $\mathrm{Se}$ & $<5 \mathrm{ppb}$ & $<5 \mathrm{ppb}$ & $<5 \mathrm{ppb}$ & $<5 \mathrm{ppb}$ & $<5 \mathrm{ppb}$ \\
\hline $\mathrm{Tl}$ & $5.72 \pm 0.17$ & $<5 \mathrm{ppb}$ & $<5 \mathrm{ppb}$ & $<5 \mathrm{ppb}$ & $9.89 \pm 0.24$ \\
\hline $\mathrm{V}$ & $64.16 \pm 0.79$ & $70.70 \pm 0.89$ & $72.49 \pm 1.01$ & $56.65 \pm 0.63$ & $0.64 \pm 0.05$ \\
\hline $\mathrm{Zn}$ & $75.74 \pm 0.95$ & $80.56 \pm 1.11$ & $69.19 \pm 0.82$ & $68.38 \pm 0.77$ & $66.99 \pm 0.69$ \\
\hline $\mathrm{Cr} \mathrm{VI}$ & $<5 \mathrm{ppb}$ & $<5 \mathrm{ppb}$ & $<5 \mathrm{ppb}$ & $<5 \mathrm{ppb}$ & $<5 \mathrm{ppb}$ \\
\hline $\mathrm{Sb}$ & $3.37 \pm 0.09$ & $2.56 \pm 0.06$ & $2.62 \pm 0.07$ & $1.49 \pm 0.03$ & $1.71 \pm 0.04$ \\
\hline & & & & &
\end{tabular}

Remarkably, higher levels of $\mathrm{Cu}$ were found in 1A soil sample, which we took at the foot of grapevines, as we expected as a consequence of the accumulation of this metal in the proximity of the trunk, deriving from the leaves fallen in autumn or by dripping of the copper-based fungicide during the phytosanitary treatments on the foliage. The soil sample (1B), taken by us as explained in Section 2.1, shows a $\mathrm{Cu}$ concentration that is about two thirds of that found in $1 \mathrm{~A}$, resulting from both fallen leaves and from mechanical activities of periodic soil tillage that lead to copper vertical and horizontal redistribution. However, these concentrations are four to six times higher than those detected in the reference soil sample (Tr), never subjected to any copper-based product treatment. Interestingly, we found a significant copper amount, four times higher than Tr, in the sample T20 taken from the site where grapevine cultivation was discontinued 20 years before the current study. This should be regarded as an average value for the soil of a former vineyard that underwent mechanical operations by plow or cutter for 20 years. The $\mathrm{Cu}$ concentration in T20 is still well-detectable probably because of a poor elimination capacity of the soil endowed with a scarce percolation and precipitation washout, and for the low $\mathrm{Cu}$ phytoextraction by spontaneous herbaceous plants or cultivated species (forage and cereals) [27]. Sample 4, constituted by branches obtained in late winter from the annual pruning (Figure 2E), did not show any significant levels of $\mathrm{Cu}$, suggesting that the grapevine plants are able to absorb only limited copper quantities, and detected amounts are the result of the metal deposition on the vine bark after the phytosanitary treatments.

\subsection{Wine Analysis}

All wines samples were evaluated by ICP-OES analysis, without undergoing any treatment, leading to the detection of metals in the quantities indicated in Table 3, which shows the results as ppb values of the various metals analyzed. Also, in this case, LOQ is $5 \mathrm{ppb}$. In general, we observed higher levels of presence of $\mathrm{Fe}, \mathrm{Al}$, and $\mathrm{Mn}$ than $\mathrm{Be}, \mathrm{Ca}, \mathrm{Hg}$, $\mathrm{K}, \mathrm{Mg}$, and $\mathrm{Cr}(\mathrm{VI})$, which are present in amounts lower than the LOQ. 
Table 3. Analysis of wine samples: Listed metal contents are means of triplicate determinations (as ppb) \pm SD.

\begin{tabular}{cccc}
\hline Metal & Sample 5 & Sample 6 & Sample 7 \\
\hline $\mathrm{Al}$ & $55.7 \pm 0.8$ & $104 \pm 3$ & $66.2 \pm 0.9$ \\
\hline $\mathrm{As}$ & $12.1 \pm 0.5$ & $8.4 \pm 0.3$ & $7.2 \pm 0.4$ \\
\hline $\mathrm{Be}$ & $<5 \mathrm{ppb}$ & $<5 \mathrm{ppb}$ & $<5 \mathrm{ppb}$ \\
\hline $\mathrm{Cd}$ & $<5 \mathrm{ppb}$ & $<5 \mathrm{ppb}$ & $<5 \mathrm{ppb}$ \\
\hline $\mathrm{Cr}$ tot & $15.3 \pm 0.3$ & $<5 \mathrm{ppb}$ & $<5 \mathrm{ppb}$ \\
\hline $\mathrm{Cu}$ & $5.76 \pm 0.04$ & $17.8 \pm 0.2$ & $12.0 \pm 0.1$ \\
\hline $\mathrm{Fe}$ & $705 \pm 10$ & $258 \pm 7$ & $1020 \pm 30$ \\
\hline $\mathrm{Hg}$ & $<5 \mathrm{ppb}$ & $<5 \mathrm{ppb}$ & $<5 \mathrm{ppb}$ \\
\hline $\mathrm{Mn}$ & $70.4 \pm 0.6$ & $50.7 \pm 0.4$ & $99.2 \pm 0.9$ \\
\hline $\mathrm{Ni}$ & $37.7 \pm 1.4$ & $<5 \mathrm{ppb}$ & $<5 \mathrm{ppb}$ \\
\hline $\mathrm{Pb}$ & $<5 \mathrm{ppb}$ & $<5 \mathrm{ppb}$ & $9.5 \pm 0.3$ \\
\hline $\mathrm{Se}$ & $20.5 \pm 0.3$ & $16.9 \pm 0.5$ & $9.1 \pm 0.4$ \\
\hline $\mathrm{Tl}$ & $<5 \mathrm{ppb}$ & $<5 \mathrm{ppb}$ & $<5 \mathrm{ppb}$ \\
\hline $\mathrm{V}$ & $<5 \mathrm{ppb}$ & $<5 \mathrm{ppb}$ & $<5 \mathrm{ppb}$ \\
\hline $\mathrm{Zn}$ & $21.6 \pm 0.2$ & $37.4 \pm 0.5$ & $211 \pm 15$ \\
\hline $\mathrm{Cr}(\mathrm{VI})$ & $<5 \mathrm{ppb}$ & $<5 \mathrm{ppb}$ & $<5 \mathrm{ppb}$ \\
\hline $\mathrm{Sb}$ & $<5 \mathrm{ppb}$ & $<5 \mathrm{ppb}$ & $<5 \mathrm{pb}$ \\
\hline & & &
\end{tabular}

Normally $\mathrm{Cu}$ levels in wines are never high and, however, are lower than the limit fixed from wine legislation of $1 \mathrm{mg} / \mathrm{L}$ [28], because the metal is partially eliminated in the lees during the fermentation process in the form of insoluble salts. However, significant $\mathrm{Cu}$ amounts are often present in industrial wines due to copper releases from the winery equipment or, more often, from direct wine treatments with copper-containing products added to improve the odor [28].

Our wine analysis showed comforting results in the quantification of various elements, and especially of $\mathrm{Cu}$. The most significant and remarkable of these, in fact, is on copper levels that are very low. This is particularly important also in consideration of the fact that industrial wines are often endowed with $\mathrm{Cu}$ levels much higher ( $>100 \mathrm{ppb}$ [29]), deriving from the direct must treatment with copper as reported in the literature. On the other side, $\mathrm{Cu}$ levels found by us are in line with (or lower than) other analytical reports on homemade wines [30].

Remarkably, the wine sample A20V, from must fermented on the grape's skins, which one could expect to lead to increased copper levels having been in direct contact with the sprayed copper products, showed the lowest value of $5.76 \pm 0.04 \mathrm{ppb}$ after the clarification. This suggests that while skins could enrich wine with copper deposited on their surfaces, on the other hand they lead to increased levels of organic compounds like polyphenols or tannins that could effectively cause metal precipitation, and in particular copper levels' decrease. The observed value was similar $(5.76 \pm 0.04 \mathrm{vs} .6 .96 \pm 0.29 \mathrm{ppb})$ to that found in a wine produced in the same year from grapes of a disease-resistant grape variety (Chambourcin, JS 26-205 [28], data not shown) that underwent no copper spray.

\section{Conclusions}

Extensive use of copper-based products and fungicides in grapevine cultivation leads to copper accumulation in vineyards higher than soils where this culture was never grown. The regular and yearly spraying of the "Bordeaux Mixture" or other copper-based phytosanitary products led to $\mathrm{Cu}$ levels higher than control even in soils where grapevine 
cultivation and consequent copper spraying was discontinued 20 years before the analysis. Even though our study revealed a very low copper content in homemade wine (much lower than that typically found in commercial wines due to copper releases from winery equipment or for the intentional addition of $\mathrm{Cu}$-based products to remove wine bad odors), the soil of a former vineyard still shows copper levels significantly higher than control soil samples after 20 years of ceasing the grapevine cultivation. This led us to reflect on the importance of limiting copper-based products in grapevine cultivation in order to protect the environment [29], benefiting leaf arthropods [15] and aquatic life, which are particularly impacted by copper accumulation [30]. In our view, the $\mathrm{Cu}$ reduction in grapevine phytosanitary treatments can be achieved by using alternative fungicides based for example on plant extracts such as neem and orange oil, and/or by growing fungus-resistant grape varieties including the so-called PIWI varieties [31,32]. In this regard, recent efforts were made to produce quality wines from the PIWI grapes, but several countries allow the production of wine for commercial purposes only from varieties belonging to the botanical species Vitis vinifera, thus excluding resistant cultivars whose cultivation, in our opinion, should be reconsidered also in Europe, considering the environmental, health, and cost benefits of PIWI. All together these approaches could bring about quality wine production with a lower environmental impact and a greater respect for aquatic life [30].

Author Contributions: All authors contributed equally to the conceptualization, literature collection, samples analysis, writing, data analysis, and editing and reviewing of the article. All authors have read and agreed to the published version of the manuscript.

Funding: This research received no external funding.

Institutional Review Board Statement: Not applicable.

Informed Consent Statement: Not applicable.

Acknowledgments: We are grateful to Roviello's family for the courtesy of giving us the possibility to perform this research on their vineyard. This review was partially written by the authors in smart-working mode (activated by University of Naples Federico II-UNINA) during the COVID-19 crisis. We dedicate this study to all the healthcare workers and to all the people who suffered and still suffer around the world because of the COVID-19 pandemic.

Conflicts of Interest: The authors declare no conflict of interest.

\section{References}

1. Unwin, T. Wine and the Vine: An Historical Geography of Viticulture and the Wine Trade; Routledge: London, UK, 2005.

2. Bois, B.; Zito, S.; Calonnec, A. Climate vs grapevine pests and diseases worldwide: The first results of a global survey. OENO One 2017, 51, 133-139. [CrossRef]

3. WaitE, H.; May, P.; BossingEr, G. Variations in phytosanitary and other management practices in Australian grapevine nurseries. Phytopathol. Mediterr. 2013, 52, 369-379.

4. Gessler, C.; Pertot, I.; Perazzolli, M. Plasmopara viticola: A review of knowledge on downy mildew of grapevine and effective disease management. Phytopathol. Mediterr. 2011, 50, 3-44.

5. Cacaj, I.; Kelmendi, B.; Hajdari, A.; Shala, N. The efficacy of spraying programmes and treatment methods against downy mildew in two grapevine cultivars in Kosovo. Arch. Phytopathol. Plant Prot. 2014, 47, 407-416. [CrossRef]

6. Wicks, T.; Magarey, P.; Wachtel, M.; Frensham, A. Effect of postinfection application of phosphorous (phosphonic) acid on the incidence and sporulation of Plasmopara viticola on grapevine. Plant Dis. 1991, 75, 40-43. [CrossRef]

7. Besnard, E.; Chenu, C.; Robert, M. Influence of organic amendments on copper distribution among particle-size and density fractions in Champagne vineyard soils. Environ. Pollut. 2001, 112, 329-337. [CrossRef]

8. Toselli, M.; Schiatti, P.; Ara, D.; Bertacchini, A.; Quartieri, M. The accumulation of copper in soils of the Italian region EmiliaRomagna. Plant Soil Environ. 2009, 55, 74-79. [CrossRef]

9. Liu, W.; Tang, M.; Tang, C.; He, J.; Yang, S.; Yang, J.; Chen, Y. Thermodynamic Research of Leaching Copper Oxide Materials with Ammonia-ammonium Chloride-water Solution. Can. Metall. Q. 2013, 49, 131-145.

10. Boudesocque, S.; Guillon, E.; Aplincourt, M.; Marceau, E.; Stievano, L. Sorption of Cu (II) onto vineyard soils: Macroscopic and spectroscopic investigations. J. Colloid Interface Sci. 2007, 307, 40-49. [CrossRef]

11. Pietrzak, U.; McPhail, D. Copper accumulation, distribution and fractionation in vineyard soils of Victoria, Australia. Geoderma 2004, 122, 151-166. [CrossRef] 
12. Fu, L.; Chen, C.; Wang, B.; Zhou, X.; Li, S.; Guo, P.; Shen, Z.; Wang, G.; Chen, Y. Differences in copper absorption and accumulation between copper-exclusion and copper-enrichment plants: A comparison of structure and physiological responses. PLoS ONE 2015, 10, e0133424. [CrossRef]

13. Allen, D.W.; Lueck, D. The organization of vineyards and wineries. In The Palgrave Handbook of Wine Industry Economics; Springer: Berlin/Heidelberg, Germany, 2019; pp. 325-337.

14. Brun, L.; Maillet, J.; Richarte, J.; Herrmann, P.; Remy, J. Relationships between extractable copper, soil properties and copper uptake by wild plants in vineyard soils. Environ. Pollut. 1998, 102, 151-161. [CrossRef]

15. Vogelweith, F.; Thiéry, D. An assessment of the non-target effects of copper on the leaf arthropod community in a vineyard. Biol. Control 2018, 127, 94-100. [CrossRef]

16. Maltman, A. The Role of Vineyard Geology in Wine Typicity. J. Wine Res. 2008, 19, 1-17. [CrossRef]

17. Renan, L. Effect of long-term applications of copper on soil and grape copper (Vitis vinifera). Can. J. Soil Sci. 1994, 74, 345-347. [CrossRef]

18. Duplay, J.; Semhi, K.; Errais, E.; Imfeld, G.; Babcsanyi, I.; Perrone, T. Copper, zinc, lead and cadmium bioavailability and retention in vineyard soils (Rouffach, France): The impact of cultural practices. Geoderma 2014, 230, 318-328. [CrossRef]

19. Mitić, S.S.; Micić, R.J.; Simonović, R.M. Analytical application of food dye Sunset Yellow for the rapid kinetic determination of traces of copper(II) by spectrophotometry. Food Chem. 2009, 117, 461-465. [CrossRef]

20. Provenzano, M.R.; El Bilali, H.; Simeone, V.; Baser, N.; Mondelli, D.; Cesari, G. Copper contents in grapes and wines from a Mediterranean organic vineyard. Food Chem. 2010, 122, 1338-1343. [CrossRef]

21. Di Mola, I.; Ottaiano, L.; Sacco, A.; Senatore, M.; Mori, M. Organic versus mineral fertilization: Assessing of yield and quality of durum wheat in marginal lands. Ital. J. Agron. 2021, 16. [CrossRef]

22. Agency-US EPA, US EPA Method 3051A: Microwave assisted acid digestion of sediments, sludges, soils, and oils. Z. Für Anal. Chem. 2007, 111, 362-366.

23. Agency-US EPA, US EPA Method 6010: Inductively coupled plasma-atomic emission spectrometry. In Test Methods for Evaluating Solid Waste, Physical/Chemical Methods (SW846); USEPA: Washington, DC, USA, 2007.

24. Martins, V.; Teixeira, A.; Bassil, E.; Blumwald, E.; Gerós, H. Metabolic changes of Vitis vinifera berries and leaves exposed to Bordeaux mixture. Plant Physiol. Biochem. 2014, 82, 270-278. [CrossRef]

25. Moutinho-Pereira, J.; Magalhaes, N.; Torres de Castro, L.; Manuela Chaves, M.; Torres-Pereira, J. Physiological responses of grapevine leaves to bordeaux mixture under light. Vitis 2001, 40, 117-121.

26. Płotka-Wasylka, J.; Frankowski, M.; Simeonov, V.; Polkowska, Ż.; Namieśnik, J. Determination of Metals Content in Wine Samples by Inductively Coupled Plasma-Mass Spectrometry. Molecules 2018, 23, 2886. [CrossRef] [PubMed]

27. Zancheta, A.C.F.; de Abreu, C.A.; Zambrosi, F.C.B.; Erismann, N.D.M.; Lagôa, A.M.M.A. Copper phytoextraction by different plant species grown in nutrient solution. Bragantia 2011, 70, 737-744. [CrossRef]

28. Feng, C.T.; Du, X.; Wee, J. Microbial and Chemical Analysis of Non-Saccharomyces Yeasts from Chambourcin Hybrid Grapes for Potential Use in Winemaking. Fermentation 2021, 7, 15. [CrossRef]

29. Peña, N.; Antón, A.; Kamilaris, A.; Fantke, P. Modeling ecotoxicity impacts in vineyard production: Addressing spatial differentiation for copper fungicides. Sci. Total Environ. 2018, 616, 796-804. [CrossRef] [PubMed]

30. Bereswill, R.; Golla, B.; Streloke, M.; Schulz, R. Entry and toxicity of organic pesticides and copper in vineyard streams: Erosion rills jeopardise the efficiency of riparian buffer strips. Agric. Ecosyst. Environ. 2012, 146, 81-92. [CrossRef]

31. Zanghelini, J.A.; Bogo, A.; Dal Vesco, L.L.; Gomes, B.R.; Mecabô, C.V.; Herpich, C.H.; Welter, L.J. Response of PIWI grapevine cultivars to downy mildew in highland region of southern Brazil. Eur. J. Plant Pathol. 2019, 154, 1051-1058. [CrossRef]

32. de Souza, A.L.K.; Brighenti, A.F.; Brighenti, E.; Caliari, V.; Stefanini, M.; Trapp, O.; Gardin, J.P.P.; Dalbó, M.A.; Welter, L.J.; Camargo, S.S. Performance of Resistant Varieties (PIWI) at Two Different Altitudes in Southern Brazil. In BIO Web of Conferences; EDP Sciences: Les Ulis, France, 2019; Volume 12, p. 01021. 